\title{
Changes in the distribution of copper and molybdenum after Mo administration and subsequent additional oral or intraperitoneal $\mathrm{Cu}$ administration to rats
}

\author{
BY H. NEDERBRAGT* \\ Zootechnical Institute, Department of Animal Nutrition, Faculty of Veterinary Sciences, \\ State University, Utrecht, The Netherlands
}

(Received 13 July 1981-Accepted 19 March 1982)

1. Male WAG/Cpb inbred rats fed on rations containing $1.5 \mathrm{mg}$ copper $/ \mathrm{kg}$ (deficient) and $6 \cdot 0 \mathrm{mg} \mathrm{Cu} / \mathrm{kg}$ (adequate) were supplemented with molybdenum $(500 \mathrm{mg} / \mathrm{kg}$ diet). Starting at week 0 rats were killed weekly for up to 6 weeks and the caeruloplasmin activity of plasma, the $\mathrm{Cu}$ concentration of plasma, liver and kidney and the Mo concentration of liver and kidney were determined. The experiment was repeated with rats fed on diets of the same composition but given additional $\mathrm{Cu}$ for periods of 2 weeks. Cu was given orally by increasing dietary $\mathrm{Cu}$ to $6.0 \mathrm{mg} / \mathrm{kg}$ and $25.0 \mathrm{mg} / \mathrm{kg}$ for $\mathrm{Cu}$-deficient and $\mathrm{Cu}$-adequate rats respectively or intraperitoneally by injecting $75 \mu \mathrm{g}$ and $250 \mu \mathrm{g}$ every second day to $\mathrm{Cu}$-deficient and $\mathrm{Cu}$-adequate rats respectively.

2. After Mo administration to $\mathrm{Cu}$-deficient rats plasma and kidney $\mathrm{Cu}$ and liver and kidney Mo increased but caeruloplasmin activity and liver $\mathrm{Cu}$ decreased. In $\mathrm{Cu}$-adequate rats plasma, liver and kidney $\mathrm{Cu}$ and liver and kidney Mo increased to much higher levels than in $\mathrm{Cu}$-deficient rats. Caeruloplasmin activity was not affected. Fluctuations in plasma $\mathrm{Cu}$ and kidney Mo were correlated closely.

3. No qualitative difference between the effect of oral or intraperitoneal $\mathrm{Cu}$ administered to Mo-treated $\mathrm{Cu}$-deficient or $\mathrm{Cu}$-adequate rats was found. In $\mathrm{Cu}$-deficient $\mathrm{Mo}$-supplemented rats additional $\mathrm{Cu}$ increased plasma $\mathrm{Cu}$, caeruloplasmin activity and liver and kidney $\mathrm{Cu}$ and $\mathrm{Mo}$. In $\mathrm{Cu}$-adequate Mo-supplemented rats additional $\mathrm{Cu}$ decreased plasma $\mathrm{Cu}$ and liver and kidney $\mathrm{Mo}$ and increased caeruloplasmin activity and kidney $\mathrm{Cu}$ and, to a minor extent, liver $\mathrm{Cu}$.

4. In view of the assumption that in rats a $\mathrm{Cu}, \mathrm{Mo}$ and $\mathrm{S}$ containing compound, related to $\mathrm{Cu}$-thiomolybdate, may be formed in vivo the results suggest that $\mathrm{Cu}$ binds to the Mo-S part of the compound; when this compound is formed in the gastro-intestinal tract it can not be absorbed and when it is formed at systemic sites it changes the $\mathrm{Cu}$ distribution.

Investigations on the copper-molybdenum-sulphur interaction has largely been concentrated on ruminants. This is due to several causes. First, sheep and cattle are the only species susceptible to Mo-induced $\mathrm{Cu}$ deficiency under field conditions; secondly, suggestions that the rumen is the main site of the interaction (Suttle, 1974) seem to be confirmed by various investigations; thirdly, single-stomached animals (non-ruminants) have not been considered as very useful experimental models.

This latter view is based on the difference between ruminants and non-ruminants in their reaction to dietary $\mathrm{Mo}$ and sulphate. In ruminants liver $\mathrm{Cu}$ concentrations are usually reduced after oral $\mathrm{Mo}$ and $\mathrm{SO}_{4}$ supplementation (Marcilese et al. 1969) whereas in non-ruminants (rats) liver $\mathrm{Cu}$ concentrations are increased after oral Mo supplementation, an effect that is alleviated by $\mathrm{SO}_{4}$ (Miller et al. 1956).

Nevertheless, Mo may have a similar effect on systemic $\mathrm{Cu}$ in both ruminants and non-ruminants. This is illustrated by the finding that in both sheep and guinea pigs after Mo supplementation, a $\mathrm{Cu}$ fraction can be demonstrated in the plasma that is insoluble in trichloroacetic acid (Smith \& Wright, 1975) whereas in sheep (Marcilese et al. 1969) as well as in rats (Compère et al. 1965; Nederbragt \& Van den Hamer, 1981 a) and rabbits (Gaballah et al. 1965) a reduced transport of injected ${ }^{64} \mathrm{Cu}$ from plasma to tissues could be observed in Mo-supplemented animals.

\footnotetext{
- Present address: Department of General Pathology, Faculty of Veterinary Sciences, State University, Biltstraat 172, 3582 BP Utrecht, The Netherlands
} 
It has been suggested that the $\mathrm{Cu}-\mathrm{Mo}$ antagonism in ruminants can be explained by the formation of unavailable $\mathrm{Cu}$-thiomolybdate complexes in the rumen and at systemic sites (Suttle, 1974; Dick et al. 1975). Furthermore it was shown in rats (Mills et al. 1978) that in vitro synthesized thiomolybdate, when administered orally, inhibited $\mathrm{Cu}$ absorption and affected systemic $\mathrm{Cu}$ distribution whereas additional dietary $\mathrm{Cu}$, but not intraperitioneal $\mathrm{Cu}$, inhibited the absorption of ${ }^{99} \mathrm{Mo}$-labelled thiomolybdate. Recently we showed (Nederbragt \& Van den Hamer, 1981 b) that the 'tightly' bound, non-caeruloplasmin $\mathrm{Cu}$ fraction in plasma of Mo-supplemented rats is part of an albumin-bound $\mathrm{Cu}-\mathrm{Mo}-\mathrm{S}$ complex that has properties similar to those of in vitro synthesized $\mathrm{Cu}$-thiomolybdate described by Mills et al. (1978), thereby confirming the suggestion that the effect of Mo on systemic $\mathrm{Cu}$ in non-ruminants may be similar to that in ruminants.

In a recent publication (Nederbragt, 1980) experiments were described in which the effects of Mo supplementation on $\mathrm{Cu}$ and Mo distributions in rats were investigated at different dietary $\mathrm{Cu}$ levels. The results showed that the effect of Mo was largely dependent on the dietary $\mathrm{Cu}$ supply; it was suggested that $\mathrm{Cu}$ may somehow affect the uptake and retention of Mo in gastrointestinal tract and tissues. Those experiments were further extended with an investigation on the effect of $\mathrm{Mo}$ on $\mathrm{Cu}$ and Mo distributions in rats as a function of time and on the influence of additional $\mathrm{Cu}$, given orally or intraperitoneally, on the Mo-induced changes. The results of these studies are presented here and are discussed with respect to the possible formation of $\mathrm{Cu}$-thiomolybdate.

\section{MATERIALS AND METHODS}

Male WAG/Cpb rats were purchased from the Centraal Proefdierenbedrijf TNO, Zeist, The Netherlands. Their weight varied from $150-200 \mathrm{~g}$ at the start of the experiment. Management, housing conditions and composition of diet have been described before (Nederbragt, 1980). All experimental groups contained six rats. In both experiments $\mathrm{Cu}$-deficient and $\mathrm{Cu}$-adequate diets were given to the rats 2 weeks prior to the start of the Mo supplementation.

In the first experiment rats were maintained either on a $\mathrm{Cu}$-deficient diet, containing $1.5 \mathrm{mg} \mathrm{Cu} / \mathrm{kg}$ or on a Cu-adequate diet, containing $6.0 \mathrm{mg} \mathrm{Cu} / \mathrm{kg}$; both diets were supplemented with Mo to a final concentration of $500 \mathrm{mg} / \mathrm{kg}$. Groups of six rats were killed weekly for up to six weeks of Mo supplementation. In the second experiment rats were maintained on diets similar to those of the first experiment. Either 2 or 4 weeks after the start of Mo supplementation to rats on the $\mathrm{Cu}$-deficient diet $(1.5 \mathrm{mg} \mathrm{Cu} / \mathrm{kg})$ additional $\mathrm{Cu}$ was given to two groups while maintaining the Mo concentration in their diets. One group of rats was supplemented with the same basal diet in which the $\mathrm{Cu}$ concentration was elevated to $6.0 \mathrm{mg} / \mathrm{kg}$. In the second group of rats, $\mathrm{Cu}$ was administered intraperitoneally by injecting $75 \mu \mathrm{g} \mathrm{Cu}$ as copper sulphate in $1 \mathrm{ml}$ saline $(9 \mathrm{~g}$ sodium chloride/1) every second day; $\mathrm{Cu}$ injections started on day 0 and were given seven times. Both groups of rats were killed 2 weeks after the start of the additional $\mathrm{Cu}$ supply and simultaneously a group of Mo-supplemented $\mathrm{Cu}$-deficient rats with unchanged $\mathrm{Cu}$ supply was sacrificed. Similar experiments were performed with $\mathrm{Cu}$-adequate rats maintained on a diet containing $6.0 \mathrm{mg} / \mathrm{kg}$. In these experiments additional $\mathrm{Cu}$ was given 1 or 3 weeks after the start of Mo-supplementation. One group of rats was given a diet in which the $\mathrm{Cu}$ concentration was elevated to $25.0 \mathrm{mg} / \mathrm{kg}$; to the second group of rats $250 \mu \mathrm{g} \mathrm{Cu}$ was administered intraperitoneally in $1 \mathrm{ml}$ saline every second day; $\mathrm{Cu}$ injections started on day 0 and were given seven times. Both groups of rats were killed 2 weeks after the start of the additional $\mathrm{Cu}$-supply and simultaneously a group of Mo-supplemented $\mathrm{Cu}$-adequate rats with unchanged Cu supply was killed.

After killing the rats, samples of blood and organs were collected for the 


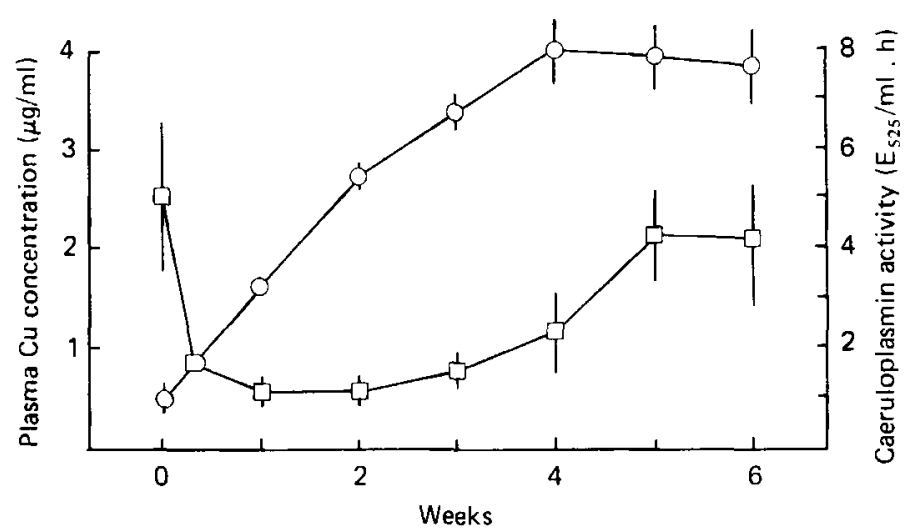

Fig. 1. Changes in the plasma copper concentration $(\mu \mathrm{g} / \mathrm{ml} ; 0-\mathrm{O})$ and caeruloplasmin activity (extinction units $\left(E_{525}\right) / \mathrm{ml}$ per $\mathrm{h} ; \square-\square$ ) of $\mathrm{Cu}$-deficient rats following dietary molybdenum supplementation. Cu level of the diet was $1.5 \mathrm{mg} / \mathrm{kg}$; Mo administration $(500 \mathrm{mg} / \mathrm{kg})$ was started at week 0 and continued throughout the experiment. Each group consisted of six rats. The points are mean values with their standard errors indicated by vertical bars.

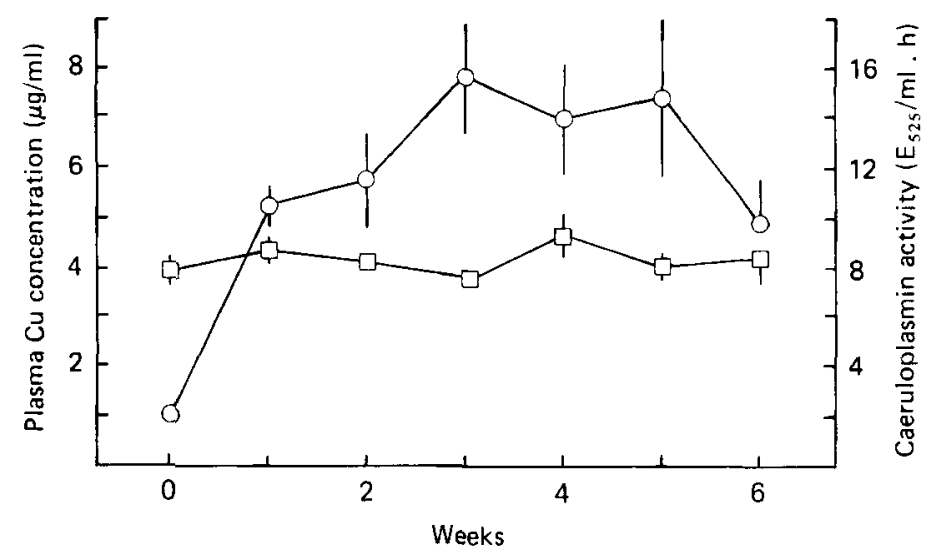

Fig. 2. Changes in the plasma copper concentration $(\mu \mathrm{g} / \mathrm{ml} ; \mathrm{O}-\mathrm{O})$ and caeruloplasmin activity (extinction units $\left(E_{525}\right) / \mathrm{ml}$ per $\mathrm{h} ; \square-\square$ ) of $\mathrm{Cu}$-adequate rats following dietary Mo supplementation. $\mathrm{Cu}$ level of the diet was $6.0 \mathrm{mg} / \mathrm{kg} ;$ Mo administration $(500 \mathrm{mg} / \mathrm{kg})$ was started at week 0 and continued throughout the experiment. Each group consisted of six rats. Points are mean values with their standard errors indicated by vertical bars.

determination of the $\mathrm{Cu}$ concentration and caeruloplasmin activity of plasma and the $\mathrm{Cu}$ and Mo concentrations of liver and kidney. The methods for these determinations have been described previously (Nederbragt, 1980). Caeruloplasmin activity is expressed as extinction at $525 \mathrm{~nm} / \mathrm{ml}$ plasma per $\mathrm{h}\left(\mathrm{E}_{525} / \mathrm{ml}\right.$ per $\left.\mathrm{h}\right)$, plasma $\mathrm{Cu}$ as $\mu \mathrm{g} / \mathrm{ml}$ and $\mathrm{Cu}$ and Mo concentrations of liver and kidney as $\mu \mathrm{g} / \mathrm{g}$ dry matter (DM).

\section{RESULTS}

\section{Expt 1. Effect of $M o$ on $\mathrm{Cu}$ and Mo distributions as functions of time}

Mo supplementation of the diet changed the distributions of $\mathrm{Cu}$ and $\mathrm{Mo}$ in plasma, liver and kidney of rats. However, a pronounced difference could be observed between the effects on $\mathrm{Cu}$-deficient and $\mathrm{Cu}$-adequate rats when the rate and extent of $\mathrm{Cu}$ and $\mathrm{Mo}$ accumulations 


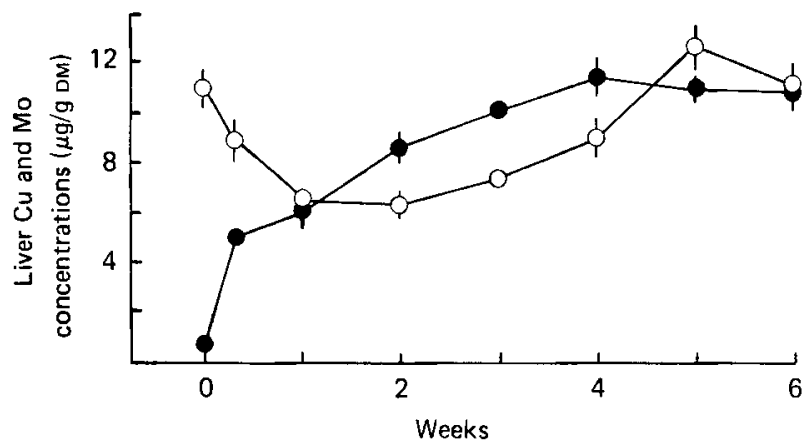

Fig. 3. Changes in the liver concentrations of copper ( $\mu \mathrm{g} / \mathrm{g}$ dry matter (DM); $\mathrm{O}-\mathrm{O})$ and molybdenum $(\mu \mathrm{g} / \mathrm{g}$ DM; - O) of Cu-deficient rats following dietary Mo supplementation. $\mathrm{Cu}$ level of the diet was $1.5 \mathrm{mg} / \mathrm{kg}$; Mo administration $(500 \mathrm{mg} / \mathrm{kg}$ ) was started at week 0 and continued throughout the experiment. Each group consisted of six rats. Points are mean values with their standard errors indicated by vertical bars.

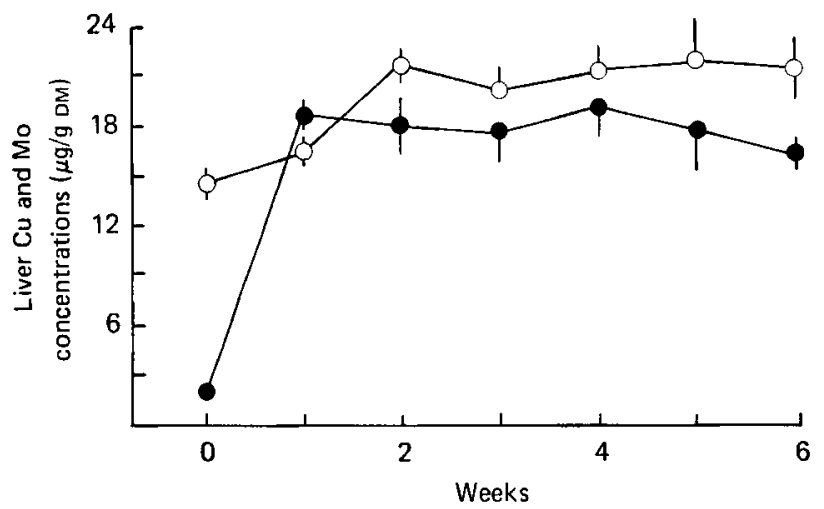

Fig. 4. Changes in the liver concentrations of copper ( $\mu \mathrm{g} / \mathrm{g}$ dry matter (DM); O-O) and molybdenum $(\mu \mathrm{g} / \mathrm{g} \mathrm{DM} ;-1)$ of $\mathrm{Cu}$-adequate rats following dietary Mo supplementation. $\mathrm{Cu}$ level of the diet was $6.0 \mathrm{mg} / \mathrm{kg}$; Mo administration $(500 \mathrm{mg} / \mathrm{kg}$ ) was started at week 0 and continued throughout the experiment. Each group consisted of six rats. Points are mean values with their standard errors indicated by vertical bars.

are concerned. This difference was obtained with a diet that contained a similar Mo concentration $(500 \mathrm{mg} / \mathrm{kg})$ for both groups of rats.

In the plasma of $\mathrm{Cu}$-deficient rats (Fig. 1) the total $\mathrm{Cu}$ concentration increased to $4.0 \mu \mathrm{g} / \mathrm{ml}$ whereas in $\mathrm{Cu}$-adequate rats a level of $7-8 \mu \mathrm{g} / \mathrm{ml}$ was reached (Fig. 2). In the $\mathrm{Cu}$-adequate rats plasma $\mathrm{Cu}$ decreased again after 5 weeks. This decrease was the start of a series of fluctuations in which plasma $\mathrm{Cu}$ was falling and rising on alternate weeks; they could be observed for up to 12 weeks after Mo administration in rats from which blood samples were taken weekly (details not shown). Although plasma $\mathrm{Cu}$ increased in $\mathrm{Cu}$-deficient rats, their caeruloplasmin activity fell rapidly after Mo administration; this was followed by a slow increase towards the end of the experiment (Fig. 1). In Cu-adequate rats the caeruloplasmin activity remained unchanged (Fig. 2).

In $\mathrm{Cu}$-deficient rats the changes in liver $\mathrm{Cu}$ (Fig. 3) were well comparable to those of their caeruloplasmin activity (Fig. 2): a decrease followed by a gradual increase. In 


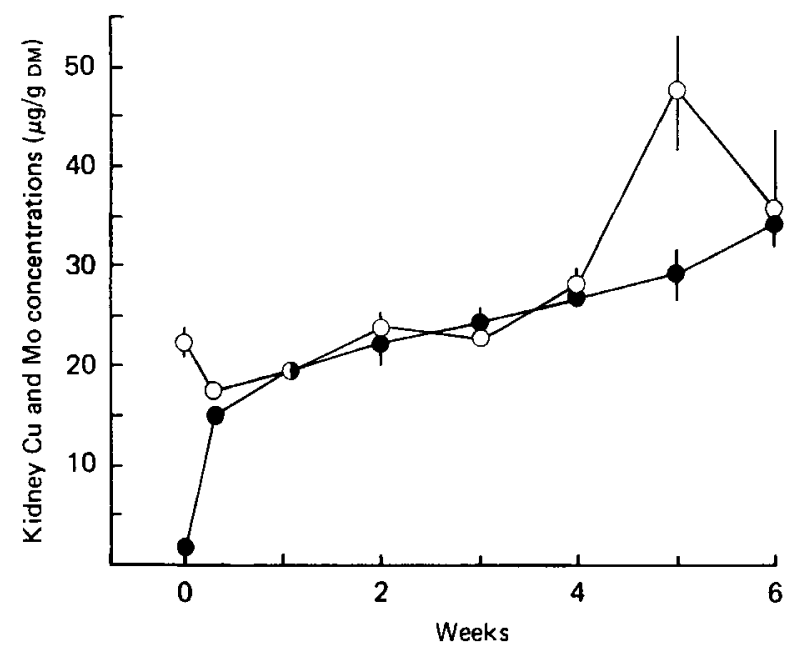

Fig. 5. Changes in the kidney concentrations of copper $(\mu \mathrm{g} / \mathrm{g}$ dry matter (DM);O-O) and molybdenum $(\mu \mathrm{g} / \mathrm{g} \mathrm{DM} ;-)$ of $\mathrm{Cu}$-deficient rats following dietary Mo supplementation. Cu level of the diet was $1.5 \mathrm{mg} / \mathrm{kg}$; Mo administration $(500 \mathrm{mg} / \mathrm{kg}$ ) was started at week 0 and continued throughout the experiment. Each group consisted of six rats. Points are mean values with their standard errors indicated by vertical bars.

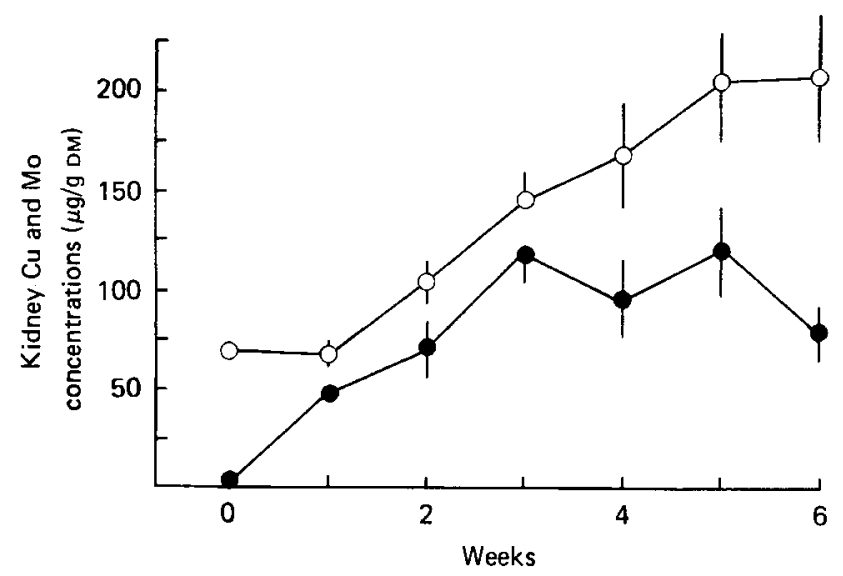

Fig. 6. Changes in the kidney concentrations of copper ( $\mu \mathrm{g} / \mathrm{g}$ dry matter (DM); $\mathrm{O}-\mathrm{O}$ ) and molybdenum ( $\mu \mathrm{g} / \mathrm{g} \mathrm{DM} ;-1$ ) of $\mathrm{Cu}$-adequate rats following dietary Mo supplementation. Cu level of the diet was $6.0 \mathrm{mg} / \mathrm{kg}$; Mo administration $(500 \mathrm{mg} / \mathrm{kg}$ ) was started at week $U$ and contınued throughout the experiment. Each group consisted of six rats. Points are mean values with their standard errors indicated by vertical bars.

$\mathrm{Cu}$-adequate rats the liver $\mathrm{Cu}$ concentration increased immediately after Mo supplementation and reached a maximum after 2 weeks (Fig. 4). A marked difference was observed in the process of Mo accumulation in the liver. In Cu-deficient rats this accumulation was slow (except for the first $2 \mathrm{~d}$; (Fig. 3)) and reached a maximum that was 0.6 of the Mo level in $\mathrm{Cu}$-adequate rats where the accumulation was very fast (Fig. 4).

The most pronounced differences were found in the kidney. In $\mathrm{Cu}$-adequate rats the net accumulation of $\mathrm{Cu}$ amounted to approximately 5 times that in $\mathrm{Cu}$-deficient rats and the Mo accumulation was at least 3 times higher in Cu-adequate rats (Figs. 5 and 6) following 


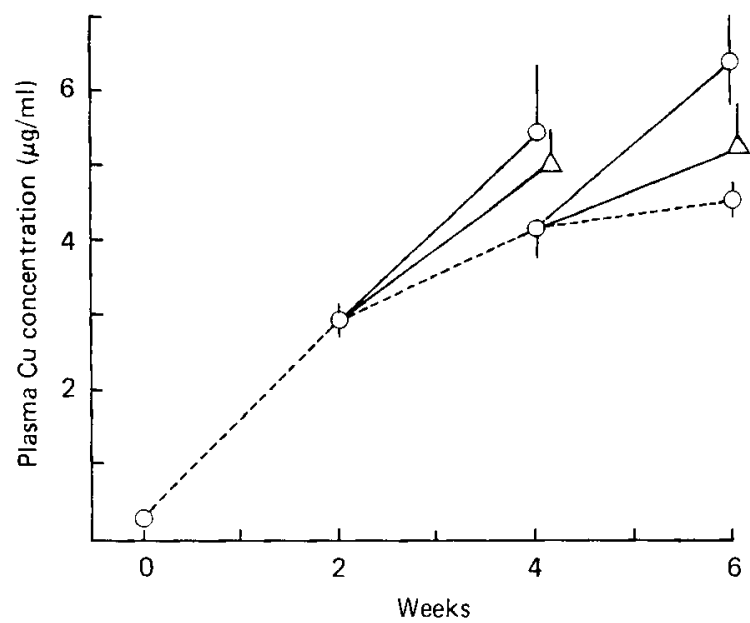

Fig. 7. Changes in the plasma copper concentration $(\mu \mathrm{g} / \mathrm{ml})$ of $\mathrm{Cu}$-deficient rats following dietary molybdenum supplementation and additional $\mathrm{Cu}$ supplementation. $\mathrm{Cu}$ leve; of the diet was $1.5 \mathrm{mg} / \mathrm{kg}$; Mo administration $(500 \mathrm{mg} / \mathrm{kg}$ ) was started at week 0 and continued throughout the experiment. (- - ), Effect of increasing the dietary $\mathrm{Cu}$ level to $6.0 \mathrm{mg} / \mathrm{kg}(\mathrm{O})$ or of intraperitoneal injections of $75 \mu \mathrm{g} \mathrm{Cu}$ each second day $(\triangle) .(--)$, No additional $\mathrm{Cu}$. Each group consisted of six rats. Points are mean values with their standard errors indicated by vertical bars.

Mo supplementation. Another feature of the changes in kidney $\mathrm{Cu}$ and Mo was the small initial decrease of $\mathrm{Cu}$ in $\mathrm{Cu}$-deficient rats (Fig. 5) and the lack of increase of $\mathrm{Cu}$ during the first week in $\mathrm{Cu}$-adequate rats (Fig. 6). In Cu-deficient rats an abrupt increase at week 5 followed by a decrease was observed (Fig. 5) that can not be explained.

\section{Expt 2. Influence of additional $\mathrm{Cu}$ on Mo-supplemented rats}

Additional $\mathrm{Cu}$ was administered, either orally or intraperitoneally, to Mo-supplemented $\mathrm{Cu}$-deficient rats for a period of 2 weeks. $\mathrm{Cu}$ was given during two different periods. The first period, between 2 and 4 weeks, corresponded to that in which plasma $\mathrm{Cu}$ in $\mathrm{Cu}$-deficient rats was still increasing; in the second period, between 4 and 6 weeks, the plasma $\mathrm{Cu}$ levels of similarly treated rats were maintained at a maximal level (Fig. 1). Dietary $\mathrm{Cu}$ was elevated from 1.5 to $6.0 \mathrm{mg} / \mathrm{kg}$ and the amount of intraperitoneally-injected $\mathrm{Cu}$ was calculated to be equivalent to that of additional dietary $\mathrm{Cu}$, assuming an intestinal $\mathrm{Cu}$ absorption in $\mathrm{Cu}$-deficient rats of 0.4 with an average daily food consumption of approximately $22 \mathrm{~g} / \mathrm{rat}$. In general, additional $\mathrm{Cu}$ caused an increase of plasma $\mathrm{Cu}$ (Fig. 7) caeruloplasmin activity (Fig. 8), liver $\mathrm{Cu}$ and Mo (Fig. 9) and kidney $\mathrm{Cu}$ and Mo (Fig. 10). Qualitative differences could not be observed between the effects of oral and intraperitoneally-injected $\mathrm{Cu}$. The increase of plasma $\mathrm{Cu}$ was more pronounced after oral $\mathrm{Cu}$ whereas caeruloplasmin activity was increased more after intraperitoneally-injected $\mathrm{Cu}$. The increase of liver $\mathrm{Cu}$ was similar when $\mathrm{Cu}$ was administered after 2 and 4 weeks of Mo supplementation but the increase in liver Mo was smaller in the second period. Kidney $\mathrm{Cu}$ concentrations increased considerably, particularly in the second period and kidney Mo concentrations were approximately doubled by the additional $\mathrm{Cu}$ administration.

Additional $\mathrm{Cu}$ was also administered, either orally or intraperitoneally, to Mosupplemented $\mathrm{Cu}$-adequate rats, for a period of 2 weeks. Cu was given during two different periods. The first period, between 1 and 3 weeks, corresponded to that in which plasma $\mathrm{Cu}$ in $\mathrm{Cu}$-adequate rats was still increasing; in the second period, between 3 and 5 weeks, 


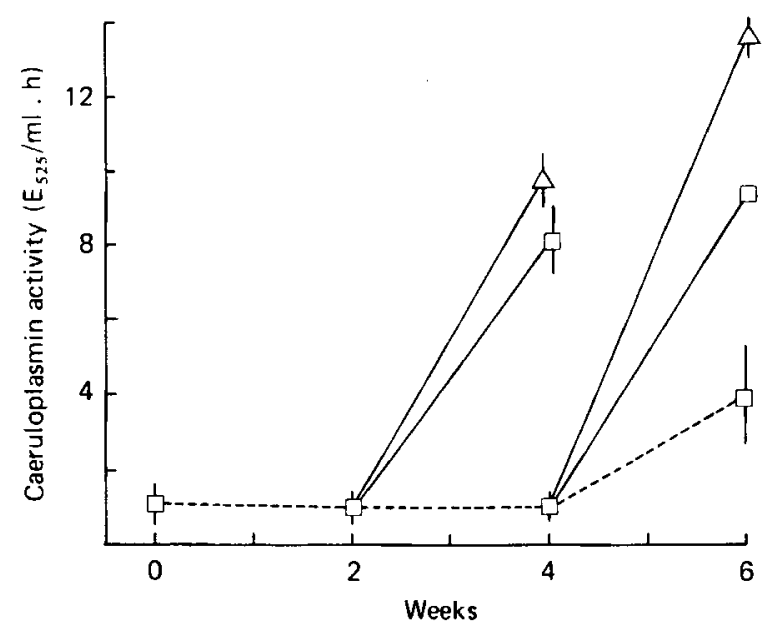

Fig. 8. Changes in the caeruloplasmin activity (extinction units $\left(E_{525}\right) / m l$ per $h$ ) in the plasma of $\mathrm{Cu}$ deficient rats following dietary molybdenum supplementation and additional $\mathrm{Cu}$ supplementation. $\mathrm{Cu}$ level of the diet was $1.5 \mathrm{mg} / \mathrm{kg}$; Mo administration $(500 \mathrm{mg} / \mathrm{kg}$ ) was started at week 0 and continued throughout the experiment. (- - , Effect of increasing the dietary $\mathrm{Cu}$ level to $6.0 \mathrm{mg} / \mathrm{kg}(\square)$ or of intraperitoneal injections of $75 \mu \mathrm{g} \mathrm{Cu}$ each second day $(\triangle)$. (-- - ), No additional $\mathrm{Cu}$. Each group consisted of six rats. Points are mean values with their standard errors indicated by vertical bars.

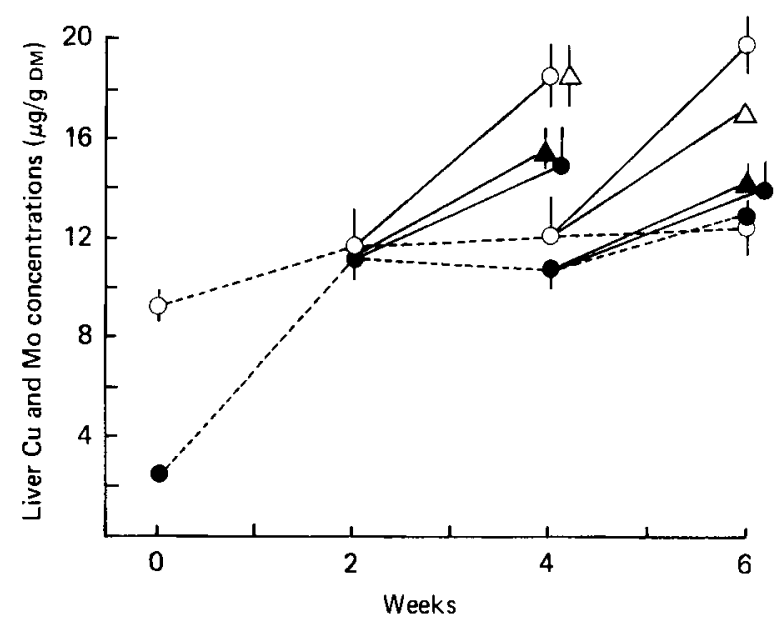

Fig. 9. Changes in the liver concentrations of copper $(\mu \mathrm{g} / \mathrm{g}$ dry matter (DM); $O, \Delta)$ and molybdenum $(\mu \mathrm{g} / \mathrm{g} \mathrm{DM} ; \mathrm{A})$ of $\mathrm{Cu}$-deficient rats following dietary Mo supplementation and additional $\mathrm{Cu}$ supplementation. Cu level of the diet was $1.5 \mathrm{mg} / \mathrm{kg}$; Mo administration $(500 \mathrm{mg} / \mathrm{kg}$ ) was started at week $\mathbf{0}$ and continued throughout the experiment. ( - ), Effect of increasing the dietary $\mathrm{Cu}$ level to $6.0 \mathrm{mg} / \mathrm{kg}(\mathrm{O}, \mathrm{O})$ or of intraperitoneal injections of $75 \mu \mathrm{g} \mathrm{Cu}$ each second day $(\triangle, \Delta)$. (- - ), No additional $\mathrm{Cu}$. Each group consisted of six rats. Points are mean values with their standard errors indicated by vertical bars.

the plasma $\mathrm{Cu}$ levels of similarly treated rats were maintained at a maximal level (Fig. 2). Dietary $\mathrm{Cu}$ was increased from 6.0 to $25.0 \mathrm{mg} / \mathrm{kg}$ and the amount of intraperitoneally-injected $\mathrm{Cu}$ was calculated to be equivalent to that of additional dietary $\mathrm{Cu}$, assuming an intestinal $\mathrm{Cu}$ absorption in $\mathrm{Cu}$-adequate rats of 0.3 with an average daily food consumption of approximately $22 \mathrm{~g} /$ rat. In general, administration of additional $\mathrm{Cu}$ caused a decrease 


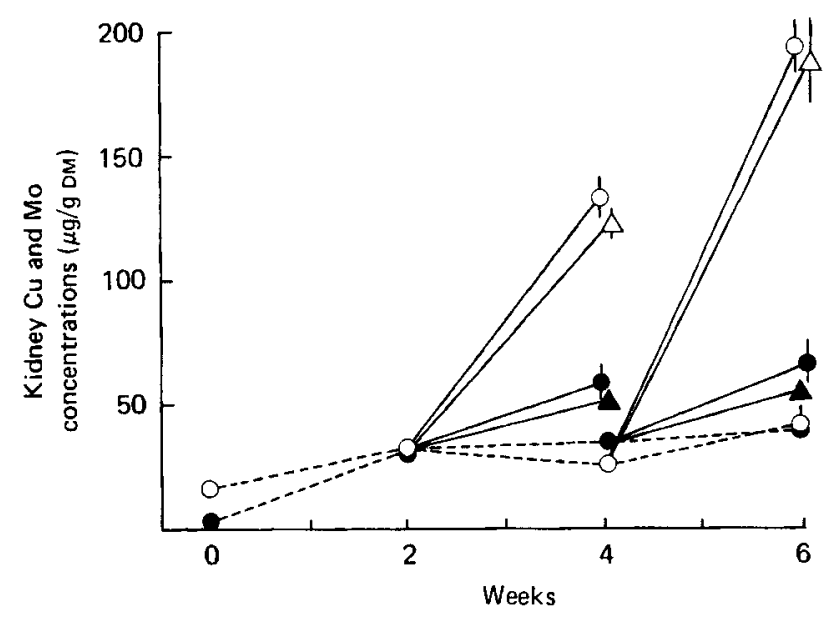

Fig. 10. Changes in the kidney concentrations of copper $(\mu \mathrm{g} / \mathrm{g}$ dry matter (DM); $O, \triangle)$ and molybdenum $(\mu \mathrm{g} / \mathrm{g} \mathrm{DM} ; \mathrm{A})$ of $\mathrm{Cu}$-deficient rats following dietary Mo supplementation and additional $\mathrm{Cu}$ supplementation. Cu level of the diet was $1.5 \mathrm{mg} / \mathrm{kg}$; Mo administration $(500 \mathrm{mg} / \mathrm{kg}$ ) was started at week 0 and continued throughout the experiment. (_-), Effect of increasing the dietary $\mathrm{Cu}$ level to $6.0 \mathrm{mg} / \mathrm{kg}$ $(\mathrm{O}, \mathrm{O})$ or of intraperitoneal injections of $75 \mu \mathrm{g} \mathrm{Cu}$ each second day $(\triangle, \mathbf{A})$. (- - ) , No additional $\mathrm{Cu}$. Each group consisted of six rats. Points are mean values with their standard errors indicated by vertical bars.

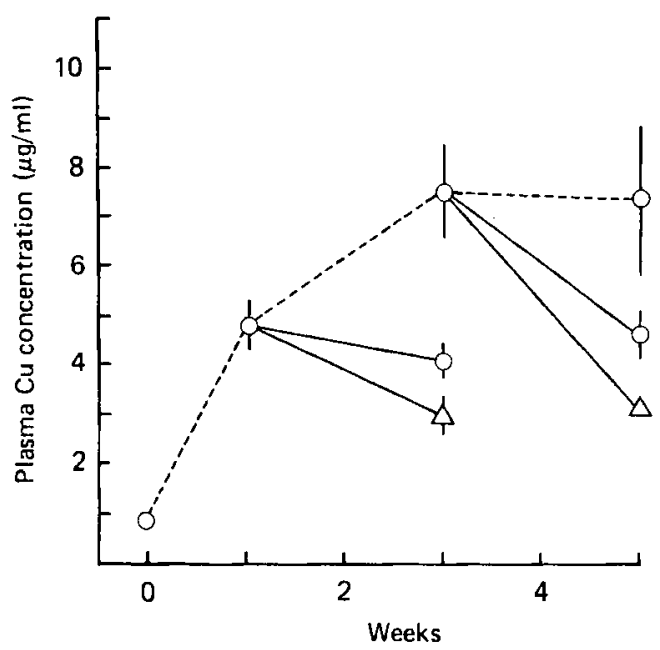

Fig. 11. Changes in the plasma copper concentration $(\mu \mathrm{g} / \mathrm{ml})$ of $\mathrm{Cu}$-adequate rats following dietary molybdenum supplementation and additional $\mathrm{Cu}$ supplementation. Cu level of the diet was $6.0 \mathrm{mg} / \mathrm{kg}$; Mo administration $(500 \mathrm{mg} / \mathrm{kg}$ ) was started at week 0 and continued throughout the experiment. (Effect of increasing the dietary Cu level to $25.0 \mathrm{mg} / \mathrm{kg} \mathrm{(O)} \mathrm{or} \mathrm{of} \mathrm{intraperitoneal} \mathrm{injections} \mathrm{of} 250 \mu \mathrm{g}$ $\mathrm{Cu}$ each second day $(\triangle) .(--)$, No additional $\mathrm{Cu}$. Each group consisted of six rats. Points are mean values with their standard errors indicated by vertical bars.

of plasma $\mathrm{Cu}$ (Fig. 11), liver Mo (Fig. 13) and kidney Mo (Fig. 14), an increase in caeruloplasmin activity (Fig. 12) and a negligible to small increase of liver $\mathrm{Cu}$ (Fig. 13) and kidney $\mathrm{Cu}$ (Fig. 14). An exception to this was observed in the liver of rats given additional $\mathrm{Cu}$ intraperitoneally between 3 and 5 weeks which caused a 2-fold increase of liver $\mathrm{Cu}$. As in $\mathrm{Cu}$-deficient rats no qualitative difference between the effect of orally- and intra- 


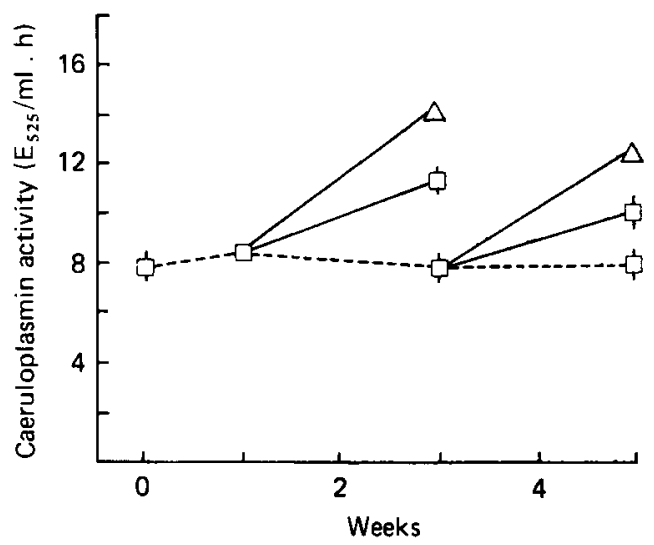

Fig. 12. Changes in the caeruloplasmin activity (extinction units $\left(E_{525} / \mathrm{ml}\right.$ per $\mathrm{h}$ ) in the plasma of $\mathrm{Cu}$-adequate rats following dietary molybdenum supplementation and additional $\mathrm{Cu}$ supplementation. $\mathrm{Cu}$ level of the diet was $6.0 \mathrm{mg} / \mathrm{kg}$; Mo administration $(500 \mathrm{mg} / \mathrm{kg})$ was started at week 0 and continued throughout the experiment. ( $\square$, Effect of increasing the dietary Cu level to $25.0 \mathrm{mg} / \mathrm{kg}(\square)$ or of intraperitoneal injections of $250 \mu \mathrm{g} \mathrm{Cu}$ each second day $(\triangle) .(--)$, No additional Cu. Each group consisted of six rats. Points are mean values with their standard errors indicated by vertical bars.

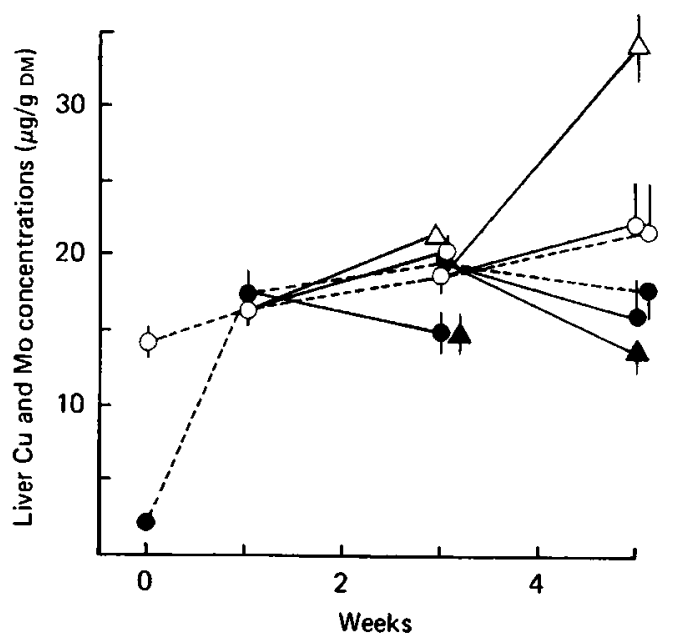

Fig. 13. Changes in the liver concentrations of copper $(\mu \mathrm{g} / \mathrm{g}$ dry matter $(\mathrm{DM}) ; 0, \Delta)$ and molybdenum $(\mu \mathrm{g} / \mathrm{g} \mathrm{DM} ; 0, \mathbf{A})$ of $\mathrm{Cu}$ adequate rats following dietary $\mathrm{Mo}$ supplementation and additional $\mathrm{Cu}$ supplementation. $\mathrm{Cu}$ level of the diet was $6.0 \mathrm{mg} / \mathrm{kg}$; Mo administration $(500 \mathrm{mg} / \mathrm{kg})$ was started at week 0 and continued throughout the experiment. (-), Effect of increasing the dietary Cu level to $25.0 \mathrm{mg} / \mathrm{kg}(\mathrm{O}, \bigcirc)$ or of intraperitoneal injections of $250 \mu \mathrm{g} \mathrm{Cu}$ each second day $(\triangle, \Delta) .(--)$, No additional $\mathrm{Cu}$. Each group consisted of six rats. Points are mean values with their standard errors indicated by vertical bars.

peritoneally-administered $\mathrm{Cu}$ was present; furthermore the mode of administration had no influence on the effect of Mo.

\section{DISCUSSION}

The studies on both $\mathrm{Cu}$-deficient and $\mathrm{Cu}$-adequate rats offer an opportunity to evaluate more closely the process that takes place after Mo administration. The evaluation presented here is based on the assumption that the formation of a compound containing $\mathrm{Cu}, \mathrm{Mo}$ and 


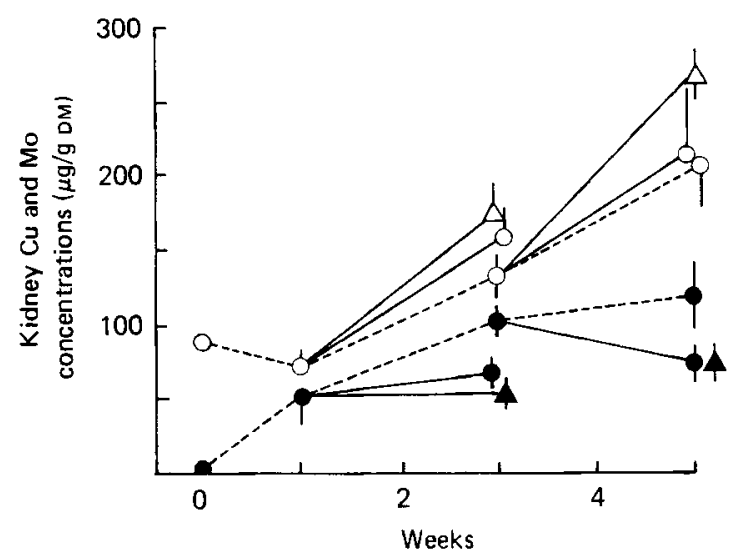

Fig. 14. Changes in the kidney concentrations of copper $(\mu \mathrm{g} / \mathrm{g}$ dry matter (DM); $O, \triangle)$ and of molybdenum $(\mu \mathrm{g} / \mathrm{g} \mathrm{DM} ; \boldsymbol{\Delta})$ of $\mathrm{Cu}$-adequate rats following dietary Mo supplementation and additional $\mathrm{Cu}$ supplementation. $\mathrm{Cu}$ level of the diet was $6.0 \mathrm{mg} / \mathrm{kg} ; \mathrm{Mo}$ administration $(500 \mathrm{mg} / \mathrm{kg})$ was started at week 0 and continued throughout the experiment. (-), Effect of increasing the dietary $\mathrm{Cu}$ level to $25.0 \mathrm{mg} / \mathrm{kg}(O, O)$ or of intraperitoneal injections of $250 \mu \mathrm{g} \mathrm{Cu}$ each second day $(\triangle, \mathbf{A}) .(-\cdots)$, No additional $\mathrm{Cu}$. Each group consisted of six rats. Points are mean values with their standard errors indicated by vertical bars.

a sulphydryl group is responsible for the observed increase in $\mathrm{Cu}$ concentrations of plasma and organs of Mo supplemented rats. This compound has been demonstrated in the plasma of those rats and it totally accounted for the increase in plasma $\mathrm{Cu}$ (Nederbragt \& Van den Hamer, $1981 b$ ).

The results with Mo administration to Cu-deficient rats (Figs. 1, 3 and 5) suggest that it is the Mo-S part of the compound that is absorbed and subsequently binds systemic $\mathrm{Cu}$. Apart from arguments derived from the experiments with additional $\mathrm{Cu}$ supply this can also be seen from the finding that despite their apparent $\mathrm{Cu}$-deficient state $(c f \mathrm{Cu}$ concentrations and caeruloplasmin activity of Cu-adequate rats in Figs. 2, 4 and 6 at $0 \mathrm{~d}$ ) Mo caused a considerable increase in plasma $\mathrm{Cu}$ but a rapid fall in caeruloplasmin activity; simultaneously liver $\mathrm{Cu}$ and, for a short time and to a lesser extent, kidney $\mathrm{Cu}$ decreased initially.

The results with $\mathrm{Mo}$ administration to $\mathrm{Cu}$-adequate rats show that there is a striking difference in the response of liver and kidney. Maximal concentrations of $\mathrm{Mo}$ and $\mathrm{Cu}$ in the liver are reached at 1 and 2 weeks respectively and are maintained for the remaining experimental period (Fig. 4). In the kidney the increase in Mo and $\mathrm{Cu}$ concentrations continues for 3 and 5 weeks respectively and the Mo concentration of the kidney starts to fluctuate after it has reached its maximum. Furthermore a high correlation $(r$ 0.94; $P<0.005)$ exists between plasma $\mathrm{Cu}$ and kidney Mo for all rats in this experiment. This finding seems to confirm the suggestion of Bremner \& Young (1978) that an unavailable $\mathrm{Cu}$ fraction (probably $\mathrm{Cu}$-thiomolybdate) may be taken up by the kidney before its excretion into the urine. Anyhow, these results show that in handling $\mathrm{Cu}$ and $\mathrm{Mo}$ in Mo-supplemented rats the role of the kidney markedly differs from that of the liver.

The effect of $\mathrm{Mo}$ administration is more dramatic in $\mathrm{Cu}$-adequate rats where $\mathrm{Cu}$ and $\mathrm{Mo}$ concentrations become several times higher than in $\mathrm{Cu}$-deficient rats (except for liver $\mathrm{Cu}$ ); this confirms earlier observations on the influence dietary $\mathrm{Cu}$ has on the effect of Mo administration in rats (Nederbragt, 1980). Furthermore it is in accordance with the results in the $\mathrm{Cu}$-deficient rats of Expt 2, where additional $\mathrm{Cu}$ administration intensified the effect of Mo administration (Figs. 7-10), although some effects (e.g. the rise in caeruloplasmin 
activity) may be due to alleviation of the $\mathrm{Cu}$-deficient state. The main effect of additional $\mathrm{Cu}$ administration should be caused by an increased storage of $\mathrm{Cu}$ and $\mathrm{Mo}$, bound together in a $\mathrm{Cu}-\mathrm{Mo}-\mathrm{S}$ compound as suggested before. Under those conditions an increased retention of Mo should be measurable as a reduced excretion of Mo into the urine because this is the main route of Mo excretion (Bibr \& Lener, 1973; Rosoff \& Spence, 1973).

Reversed results are obtained when $\mathrm{Cu}$ is administered to Mo-supplemented $\mathrm{Cu}$-adequate rats (Figs. 11-14): plasma $\mathrm{Cu}$ and liver and kidney Mo are decreased (or are not further increased as in the kidney between 1 and 3 weeks) whereas liver and kidney $\mathrm{Cu}$ are mostly slightly increased; the rise in caeruloplasmin activity is more substantial and suggests that the $\mathrm{Cu}$ supply of these rats is not optimal. The observed decreases of plasma $\mathrm{Cu}$ and liver and kidney Mo provide a second argument for the suggestion that an Mo-S compound is formed in the gastrointestinal tract: the presence of a large amount of dietary $\mathrm{Cu}$ may give rise to a higher concentration of a $\mathrm{Cu}-\mathrm{Mo}-\mathrm{S}$ compound in the gastrointestinal tract and, as it cannot be absorbed, less of the Mo-S compound is available at systemic sites for $\mathrm{Cu}$ binding. That $\mathrm{Cu}$ has no effect on molybdate is shown by Mason et al. (1978) who found no influence of additional $\mathrm{Cu}$ on the absorption of ${ }^{99} \mathrm{Mo}$ administered as molybdate to sheep via the duodenum and furthermore by the lack of influence of intraperitoneallyinjected $\mathrm{Cu}$ on the retention of ${ }^{99} \mathrm{Mo}$-labelled molybdate that was administered intravenously to rats (Nederbragt and Van den Hamer, unpublished results).

In a recent paper (Nederbragt \& Van den Hamer, 1981 b) it was suggested that the $\mathrm{Cu}-\mathrm{Mo-S}$ complex that was demonstrated in the plasma of Mo-treated rats was related to $\mathrm{Cu}$-thiomolybdate (CuTM). For the suggested formation of an Mo-S compound or thiomolybdate (TM) in the gastrointestinal tract of the rat there is no direct evidence. However, it has been shown that micro-organisms in the intestinal lumen of the rat are involved in the metabolism of S-containing compounds (Huovinen \& Gustafsson, 1967) which may be influenced by the presence of molybdate as it is in rumen micro-organisms (Gawthorne \& Nader, 1976). Furthermore the finding that oral $\mathrm{Cu}$ inhibits the absorption of orally administered ${ }^{99}$ Mo-labelled TM (Mills et al. 1978) confirms the suggested physiological behaviour of the Mo-S compound and its relation to TM.

The amount of $\mathrm{Cu}$ to be injected was chosen somewhat arbitrarily because no convincing data could be found concerning the efficiency of $\mathrm{Cu}$ absorption under the different conditions used in these experiments. Nevertheless no qualitative and only small quantitative differences were found between the effect of oral and intraperitoneally-injected $\mathrm{Cu}$. This may indicate that in $\mathrm{Mo}$-supplemented $\mathrm{Cu}$-adequate rats $\mathrm{Cu}$ excreted into the bile should behave similarly to oral $\mathrm{Cu}$. Although it is assumed that little re-absorption of biliary $\mathrm{Cu}$ occurs in rats nothing is known of the binding of $\mathrm{Cu}$ to biliary compounds; it cannot be excluded that the $\mathrm{Cu}$-chelating properties of $\mathrm{TM}$ in the intestine are equal to those of $\mathrm{TM}$ at systemic sites and therefore binding of $\mathrm{Cu}$ from biliary proteins may inhibit the absorption of TM.

Although further experimentation is necessary, the results of this study strongly support the hypothesis that the formation of CuTM-related compounds may occur in the gastrointestinal tract and in plasma and tissues of non-ruminants.

\section{REFERENCES}

Bibr, B. \& Lener, J. (1973). Physiol. bohemoslov. 22, 167.

Bremner, I. \& Young, B. W. (1978). Br. J. Nutr. 39, 325.

Compère, R., Burny, A., Riga, A., François, E. \& Vanuytrecht, S. (1965). J. Nutr. 87, 412.

Dick, A. T., Dewey, D. W. \& Gawthorne, J. M. (1975). J. agric. Sci., Camb. 85, 567.

Gaballah, S. S., Abood, L. G., Kapsalis, A. \& Sturdivant, D. (1965). Proc. Soc. exp. Biol. Med. 119, 625.

Gawthorne, J. M. \& Nader, C. J. (1976). Br. J. Nutr. 35, 11.

Huovinen, J. A. \& Gustafsson, B. E. (1967). Biochem. biophys, Acta 136, 441. 
Marcilese, N. A., Ammerman, C. B., Valsecchi, R. M., Dunavant, B. G. \& Davis, G. K. (1969). J. Nutr. 99, 177. Mason, J., Lamand, M., Tressol, J. C. \& Lab, C. (1978). Ann. Rech. vet. 9, 557.

Miller, R. F., Price, N. O. \& Engel, R. W. (1956). J. Nutr. 60, 539.

Mills, C. F., Bremner, I., El-Gallad, T. T., Dalgarno, A. C. \& Young, B. W. (1978). In Trace Element Metabolism in Man and Animals, vol. 3, p. 150 [M. Kirchgessner, editor]. Freising-Weihenstephan: Arbeitskreis Tierernährungforschung.

Nederbragt, H. (1980). Br. J. Nutr. 43, 329.

Nederbragt, H. \& Van den Hamer, C. J. A. (1981 a). J. inorg. Biochem. 15, 281.

Nederbragt, H. \& Van den Hamer, C. J. A. $(1981$ b). J. inorg. Biochem. 15, 293.

Rosoff, B. \& Spence, H. (1973). Health Phys. 25, 173.

Smith, B. S. W. \& Wright, H. (1975). Clin. chim. Acta 62, 55.

Suttle, N. F. (1974). Proc. Nutr. Soc. 33, 299. 